\title{
Prognostic indicators in acute pancreatitis
}

\author{
Clement W Imrie MB ChB FRCS
}

CW Imrie. Prognostic indicators in acute pancreatitis. Can J Gastroenterol 2003;17(5):325-328.

Several approaches have been used in an attempt to predict the severity and prognosis of attacks of acute pancreatitis. The Ranson and Glasgow criteria include a variety of simple laboratory parameters that are measured on admission and again within $48 \mathrm{~h}$. They are the most widely used indices in clinical practice. The Acute Physiological and Chronic Health Evaluation II system is more complicated, but can be applied to a wide variety of conditions, especially in intensive care settings. The usefulness of this system depends on the threshold score for defining severe pancreatitis; a score of eight appears to be the most appropriate. The finding of nonperfused areas in the pancreas at contrast-enhanced computed tomography is indicative of pancreatic necrosis and portends an unfavourable prognosis. Other clinical and laboratory indices have been proposed, but the most important predictive factor of early mortality seems to be the presence and persistance of a Marshall organ failure score of two or more. This is especially true if organ dysfunction persists beyond 36 h. Radiological findings do not always correlate well with the presence of organ dysfunction, and more investigations are required.

Key Words: Dynamics of multiple organ dysfunction syndrome; MODS

\section{Des indicateurs pronostiques en cas de pancréatite aiguë}

Diverses démarches ont été utilisées dans une tentative pour prévoir la gravité et le pronostic de crises de pancréatite aiguë. Les critères de Ranson et de Glasgow incluent divers paramètres de laboratoire simples mesurés au moment de l'hospitalisation puis 48 heures plus tard. Ce sont les indices cliniques les plus utilisés en pratique clinique. Le système Acute Physiological and Chronic Health Evaluation II est plus complexe, mais il peut s'appliquer à toute une gamme de pathologies, surtout aux soins intensifs. L'utilité de ce système dépend de l'indice seuil de définition d'une pancréatite grave. Un indice de huit semble le plus pertinent. L'observation d'arcs non perfusés dans le pancréas à la tomodensitométrie avec injection de contraste est indicative d'une nécrose pancréatique et présage un pronostic défavorable. D'autres indices cliniques et de laboratoire ont été proposés, mais le facteur prédictif le plus important de mortalité précoce semble être une défaillance multiorganique. C'est particulièrement vrai si la dysfonction organique persiste plus de 36 heures. Les observations radiologiques ne sont pas toujours bien corrélées en présence d'une dysfonction organique, et d'autres examens s'imposent.
Ev ver since the pioneering work by John Ranson in 1974, a variety of approaches have been used in an effort to identify, at an early stage, the minority of patients with acute pancreatitis (AP) who are at the most risk for severe complications and death. Although Ranson's original criteria applied to alcohol-related AP (1), the criteria were modified in 1979 for use in patients with gallstone-induced disease (2). Amazingly, the latter have been used by very few clinicians or investigators. The original and modified Ranson criteria are listed in Table 1. The modified Glasgow criteria, in which the original 11 Ranson criteria were reduced to eight, were shown in 1984 to be equally applicable to both of the major causes of AP (3). They are listed in Table 2.

The Acute Physiological and Chronic Health Evaluation (APACHE) II system (Table 3) (4) has been increasingly employed, especially since 1989 , as a means of grading the severity of pancreatitis and of other serious medical and surgical conditions. Unfortunately, the very large multinational study of the platelet activating factor antagonist, lexipafant, used this system but included a group of 1508 patients with supposedly severe AP who had a mortality rate of only $8 \%$ (5). This study used a minimum APACHE II score of six on admission as an inclusion criterion, but most investigators now believe that a score of eight is more appropriate as a threshold for the identification of severe AP. Ranson (using the correct score for the population in question), Glasgow and APACHE II are all reasonably valuable for group analysis, but are too inaccurate for the individual at-risk patient.

Obesity, as defined by a body mass index of $30 \mathrm{~kg} / \mathrm{m} 2$ or greater, is associated with increased morbidity and mortality in patients with AP (6). In addition, patients who are at least 70 years of age have a mortality of $16 \%$ to $20 \%(1-3,7-10)$. The presence of chest $\mathrm{x}$-ray abnormalities, especially pleural effusions at admission, predicts a poor prognosis, especially when combined with hypoxemia (arterial oxygen level less than $60 \mathrm{mmHg}$ ) (1-4,9-15). Therefore, a cheap but as yet untested combination of prognostic factors would be body mass index, age, chest $\mathrm{x}$-ray and oxygen saturation.

This article was originally presented at the 15th International Course on Therapeutic Endoscopy, hosted by the Wellesley Group, Division of Gastroenterology, St Michael's Hospital, Toronto, Ontario, October 9-12, 2002

Royal Infirmary, Glasgow, Scotland

Correspondence: Dr Clement W Imrie, Royal Infirmary, 16 Alexandra Parade, Glasgow, Scotland G31 2ER, United Kingdom.

Telephone +0141-211-4293, fax +0141-211-4991 
TABLE 1

Ranson criteria

\begin{tabular}{lcc}
\hline Parameter & Alcohol-induced $^{*}$ & Gallstone-induced $^{\dagger}$ \\
\hline On admission & & \\
Age $($ years $)$ & $>55$ & $>70$ \\
WBC/mL & $>16,000$ & $>18,000$ \\
Glucose (mg/dL) & $>200$ & $>220$ \\
LDH (IU/L) & $>350$ & $>400$ \\
AST (IU/L) & $>250$ & $>250$ \\
Within 48 h & $>10$ & \\
Hct decreases (points) & $>5$ & $>2$ \\
BUN increases (mg/dL) & $<8$ & $<8$ \\
Calcium (mg/DL) & $<60$ & \\
PaO & (mmHg) \\
Base deficit (mEq/L) & $>4$ & $>5$ \\
Fluid $(\mathrm{L})(\mathrm{I}-\mathrm{O})$ & $>6$ & $>4$ \\
\hline
\end{tabular}

${ }^{*}$ From Ranson et al (1); trom Ranson et al (2). AST Aspartate transaminase; BUN Blood urea nitrogen; Hct Hematocrit; I - O Intake minus output; LDH Lactic dehydrogenase; $\mathrm{PaO}_{2}$ Arterial partial pressure of oxygen; WBC White blood cell count

C-reactive protein is a single marker that is very useful in determining the severity of the disease $(16-20)$. However, because it is an acute phase reactant produced in the liver, it does not peak until approximately $36 \mathrm{~h}$ after the onset of symptoms. This limitation is similar to that which plagues the Ranson and Glasgow criteria, which require assessment $48 \mathrm{~h}$ after admission. Patients with severe AP almost invariably have a C-reactive protein greater than $150 \mathrm{mg} / \mathrm{L}$, but a skew distribution of results makes this test occasionally unreliable.

Johnson and colleagues (21) at Southampton proposed that obesity be added to the APACHE II scoring system, thus creating the APACHE-O system. Although this combination seems promising, it has not been employed in any major prospective study by another research group.

The Atlanta Criteria, developed in 1992, reflect the fact that major organ compromise at an early stage correlates with the presence of severe AP (22). Moreover, the prognosis is worsened in patients who develop major complications later in the course of disease, such as a pseudocyst, infection or pancreatic necrosis, but transient organ failure (less than $36 \mathrm{~h}$ ) is not associated with hight mortality and morbidity.

Many have stated that the gold standard for severe AP is evidence, at contrast-enhanced computed tomography (CT), of reduced perfusion or infarction of the pancreas $(19,23-31)$. This criterion has been used to select patients for many trials of early antibiotic therapy. In general clinical practice, however, this test is rarely performed during the initial $24 \mathrm{~h}$ after admission. It is more sensible to perform this test on patients who are seriously ill 48 to $72 \mathrm{~h}$ later.
TABLE 2

Modified Glasgow criteria

Parameter

Age (years) > >55

White blood cell count $/ \mathrm{mL}$

Glucose (mg/dL)

Blood urea nitrogen $(\mathrm{mg} / \mathrm{dL})$

$>15,000$

$>180$

Arterial partial pressure of oxygen $(\mathrm{mmHg})$

$>96$

Calcium $(\mathrm{g} / \mathrm{dL})$

$<60$

Albumin (g/dL)

$<8$

$<3.2$

Lactic dehydrogenase (IU/L)

$>600$

Data from Blamey et al (3).

The most important prognostic marker of severe disease is objective evidence of significant organ dysfunction, as reflected by the multiple organ dysfunction (MODS) scoring system (32). Failure of two or more organ systems constitutes MODS. It is important to realize that organ failure can occur very early in the course of acute pancreatitis.

The author's group in Glasgow has recently shown that the dynamics of organ function are very important. Organ failure, or deterioration of organ function, that persists for more than $36 \mathrm{~h}$ is associated with mortality rates of $50 \%$ to $60 \%$, whereas patients with only transient organ dysfunction rarely die from the disease (33). This concept requires validation by clinical trials. Traditional prognostic indices may be deficient, because they do not address the time-course of organ dysfunction. Employing Marshall or similar scores (32) can more clearly identify the maximal risk patients (Table 4 ).

Some investigators believe that there is an excellent correlation between CT evidence of pancreatic damage and clinical organ failure, but this view is not universally held, and more studies are required. The presence of MODS in the first week of illness may account for up to 50\% of all deaths from AP in most prospective studies. On the other hand, most deaths that occur after the first week of illness are associated with the presence of infected necrosis of the pancreas and also MODS

In conclusion, much work still needs to be done in establishing early prognostic factors for acute pancreatitis. Traditional indices that employ clinical findings and laboratory tests are subject to limitations. Contrast-enhanced CT scanning is also useful, but is generally not undertaken early in the course of disease and may exacerbate renal failure. Although MODS is highly predictive, it would be ideal to identify patients who require intensive therapy before the development of severe dysfunction. Exciting new work on the dynamics of organ dysfunction may offer a lead to this important clinical dilemma.

TABLE 3

APACHE-II system

\begin{tabular}{|c|c|c|c|c|c|c|c|c|c|}
\hline \multirow[b]{2}{*}{ Physiological variable } & \multicolumn{4}{|c|}{ High abnormal range } & \multirow{2}{*}{$\begin{array}{c}\text { Normal } \\
0\end{array}$} & \multicolumn{3}{|c|}{ Low abnormal range } & \multirow[b]{2}{*}{+4} \\
\hline & +4 & +3 & +2 & +1 & & +1 & +2 & +3 & \\
\hline Temperature $\left(\right.$ rectal $\left.{ }^{\circ} \mathrm{C}\right)$ & $\geq 41$ & $39-40.9$ & & $38.5-38.9$ & $36-38.4$ & $34-35.9$ & $32-33.9$ & $30-31.9$ & $\leq 29.9$ \\
\hline $\begin{array}{l}\text { Mean arterial pressure } \\
(\mathrm{mmHg})\end{array}$ & $\geq 160$ & $130-159$ & $110-129$ & & $70-109$ & & $50-69$ & & $\leq 49$ \\
\hline Heart rate & $\geq 180$ & $140-179$ & $110-139$ & & $70-109$ & & $55-69$ & $40-54$ & $\leq 39$ \\
\hline Respiratory rate & $\geq 50$ & $35-49$ & & $25-34$ & $12-24$ & $10-11$ & $6-9$ & & $\leq 5$ \\
\hline
\end{tabular}


TABLE 3 (continued)

APACHE-II system

\begin{tabular}{|c|c|c|c|c|c|c|c|c|c|}
\hline \multirow[b]{2}{*}{ Physiological variable } & \multicolumn{4}{|c|}{ High abnormal range } & \multirow{2}{*}{$\begin{array}{c}\text { Normal } \\
0\end{array}$} & \multicolumn{4}{|c|}{ Low abnormal range } \\
\hline & +4 & +3 & +2 & +1 & & +1 & +2 & +3 & +4 \\
\hline \multicolumn{10}{|l|}{ Oxygenation (mmHg) } \\
\hline $\begin{array}{l}\mathrm{F}_{\mathrm{i}} \mathrm{O}_{2} \geq 0.5- \\
\quad \text { record }(\mathrm{A}-\mathrm{a}) \mathrm{PO}_{2}\end{array}$ & $\geq 500$ & $350-499$ & $200-349$ & & $<200$ & & & & \\
\hline $\begin{array}{l}\mathrm{F}_{\mathrm{i}} \mathrm{O}_{2}<0.5- \\
\quad \text { record only } \mathrm{P}_{\mathrm{a}} \mathrm{O}_{2}\end{array}$ & & & & & $>70$ & $61-70$ & & $55-60$ & $<55$ \\
\hline Arterial $\mathrm{pH}$ & $\geq 7.7$ & 7.6-7.69 & & $7.5-7.59$ & 7.33-7.49 & & $7.25-7.32$ & $7.15-7.24$ & $<7.15$ \\
\hline Serum sodium (mMol/L) & $\geq 180$ & $160-179$ & $155-159$ & $150-154$ & $130-149$ & & $120-129$ & $111-119$ & $<111$ \\
\hline Serum potassium (mMol/L) & $\geq 7$ & $6-6.9$ & & $5.5-5.9$ & $3.5-5.4$ & 3-3.4 & $2.5-2.9$ & & $<2.5$ \\
\hline $\begin{array}{l}\text { Serum creatinine }(\mathrm{mg} / \mathrm{dL}) \\
\quad \text { (double score for acute failure) }\end{array}$ & $\geq 3.5$ & $2-3.4$ & $1.5-1.9$ & & $0.6-1.4$ & & $<0.6$ & & \\
\hline Hematocrit (\%) & $\geq 60$ & & $50-59.9$ & $46-49.9$ & $30-45.9$ & & $20-29.9$ & & $<20$ \\
\hline White blood count & $\geq 40$ & & $20-39.9$ & $15-19.9$ & $3-14.9$ & & $1-2.9$ & & $<1$ \\
\hline
\end{tabular}

$\left(\times 10^{3} / \mathrm{mm}^{3}\right)$

Glasgow Coma Scale (15-GCS)

A. Total acute physiology score (sum of above 12 items)

Serum $\mathrm{HCO}_{3}^{-} \quad \geq 52 \quad 41-51.9$

(venous $\mathrm{mMol} / \mathrm{L}$ ) (use only if ABGs not available)

Assign points to age as follows:

$\begin{array}{cc}\text { Age (years) } & \text { Points } \\ \leq 44 & 0 \\ 45-54 & 2 \\ 55-64 & 3 \\ 65-74 & 5 \\ \geq 75 & 6\end{array}$

Add points if the patient has evidence of severe organ system insufficiency or is immunocompromised

5 points for medical or emergency postoperative patients

2 points for elective postoperative patients

APACHE-II score $=\mathrm{A}+\mathrm{B}+\mathrm{C}$

From Knaus et al (4). (A-a) $\mathrm{PO}_{2}$ Alveolar-arterial oxygen gradient; ABG Arterial blood gas; $\mathrm{F}_{i} \mathrm{O}_{2}$ Fraction of inspired oxygen; $\mathrm{HCO}{ }_{3}^{-}$Bicarbonate; $\mathrm{P}_{\mathrm{a}} \mathrm{O}_{2}$ Arterial partial pressure of oxygen

\section{TABLE 4}

Modified Marshall organ failure score (hepatic index excluded)

\begin{tabular}{|c|c|c|c|c|c|}
\hline & & & Score & & \\
\hline & 0 & 1 & 2 & 3 & 4 \\
\hline $\begin{array}{l}\text { Cardiovascular system } \\
\text { (systolic blood pressure) }\end{array}$ & $>90$ & $<90$, fluid responsive & $<90$, negative fluid response & $<90, \mathrm{pH}<7.3$ & $<90, \mathrm{pH}<7.2$ \\
\hline $\begin{array}{l}\text { Respiratory system } \\
\left(\mathrm{F}_{\mathrm{i}} \mathrm{O}_{2} / \mathrm{PO}_{2}\right)\end{array}$ & $>400$ & $301-400$ & $201-300$ & $101-200$ & $<101$ \\
\hline Glasgow coma score & 15 & $13-14$ & $10-12$ & $6-9$ & $<6$ \\
\hline $\begin{array}{l}\text { Coagulation } \\
\left.\text { (platelet count } \times 10^{9} / \mathrm{L}\right)\end{array}$ & $>120$ & $81-120$ & $51-80$ & $21-50$ & $<21$ \\
\hline $\begin{array}{l}\text { Renal } \\
\qquad \text { (creatinine, } \mu \mathrm{mol} / \mathrm{L} \text { ) }\end{array}$ & $<134$ & $134-169$ & $170-310$ & $311-439$ & $>439$ \\
\hline
\end{tabular}

Data from reference 32. $\mathrm{F}_{\mathrm{i}} \mathrm{O}_{2}$ Fraction of inspired oxygen; $\mathrm{PO}_{2}$ Pressure of oxygen

\section{REFERENCES}

1. Ranson JHC, Rifkind KM, Roses DF, Fink SD, Eng K, Spencer FC.

Prognostic signs and the role of operative management in acute pancreatitis. Surg Gynecol Obstet 1974;139:69-81.

2. Ranson JHC. The timing of biliary surgery in acute pancreatitis. Ann Surg 1979;189:654-62.

3. Blamey SL, Imrie CW, O’Neill J, Gilmour WH, Carter DC.

Prognostic factors in acute pancreatitis. Gut 1984;25:1340-6.
4. Knaus WA, Draper EA, Wagner DP, Zimmerman JE. APACHE II: A severity of disease classification system. Crit Care Med $1985 ; 13: 818-29$

5. Larvin M, Ammori B, McMahon MJ. A double blind randomised placebo controlled multicentre trial to evaluate the efficacy and safety at two doses of lexipafant in acute pancreatitis therapy. Pancreatology 2001;1:279. (Abst) 
6. Lankisch PG, Schirren CA. Increased body weight as a prognostic parameter for complications in the course of acute pancreatitis. Pancreas 1990;5:626-9.

7. Fan ST, Choi TK, Lai CS, Wong J. Influence of age on the mortality from acute pancreatitis. Br J Surg 1988;75:463-6.

8. Tran DD, Cuesta MA, Schneider AJ, Wesdorp RI. Prevalence and prediction of multiple organ system failure and mortality in acute pancreatitis. J Crit Care 1993;8:145-53.

9. McKay CJ, Evans S, Sinclair M, et al High early mortality rate from acute pancreatitis in Scotland. A 12 years national study 1984 1995. Br J Surg 1999;86:1302-5.

10. Halonen KI, Leppaniemi AK, Puolakkainen PA, et al. Severe acute pancreatitis: Prognostic factors in 270 consecutive patients Pancreas 2000;21:266-71.

11. Jacobs ML, Daggett WM, Civette JM, et al. Acute pancreatitis: Analysis of factors influencing survival. Ann Surg 1977;185:43-51.

12. Satiani B, Stone HH. Predictability of present outcome and future recurrence in acute pancreatitis. Arch Surg 1979;114:711-6.

13. Puolakkainen P, Lempinen M, Schroder T. Fatal pancreatitis. A study of 64 consecutive cases. Acta Chir Scand 1986;152:379-83.

14. Basran GS, Ramasubramanian R, Verma R. Intrathoracic complications of acute pancreatitis. Br J Dis Chest 1987;81:326-31.

15. Lankisch PG, Droge M, Becher R. Pulmonary infiltrations. Sign of severe acute pancreatitis. Int J Pancreatol 1996;19:113-5.

16. Mayer AD, McMahon MJ, Bowen, Cooper EH. C reactive protein: An aid to assessment and monitoring of acute pancreatitis. J Clin Pathol 1984;37:207-11.

17. Puolakkainen P, Valtonen V, Paananen A, Schroder T. C-reactive protein (CRP) and serum phospholipase A2 in the assessment of the severity of acute pancreatitis. Gut 1987;28:764-71.

18. Leese T, Shaw D, Holliday M. Prognostic markers in acute pancreatitis: Can pancreatic necrosis be predicted? Ann R Col Surg Engl 1988;70:227-32.

19. Puolakkainen PA. Early assessment of acute pancreatitis. A comparative study of computed tomography and laboratory tests. Acta Chir Scand 1989;155:25-30

20. Wilson C, Heads A, Shenkin A, Imrie CW. C-reactive protein, antiproteases and complement factors as objective markers of severity in acute pancreatitis. Br J Surg 1989;76:177-81.

21. Toh SKC, Walters J, Johnson CD. APACHE-O: A new predictor of severtity in acute pancreatitis. Gut 1996;38(Suppl 1):35. (Abst)

22. Bradley EC. A clinically based classification system for acute pancreatitis. Summary of the International Symposium on Acute Pancreatitis, Atlanta, Georgia, September 11-13 1992. Arch Surg 1993;128:586-90.

23. Kivisaari L, Somer K, Standertskjold-Nordenstam C-J, Schroder T, Kivilaakso E, Lempinen M. A new method for the diagnosis of acute hemorrhagic-necrotizing pancreatitis using contrast-enhanced CT. Gastrointest Radiol 1984;9:27-30.

24. Ranson JHC, Balthazar E, Caccavale R, Cooper M. Computed tomography and the prediction of pancreatic abscess in acute pancreatitis. Ann Surg 1985;201:656-65.

25. Nordestgaard AG, Wilson SE, Williams RA. Early computerized tomography as a predictor of outcome in acute pancreatitis. Am Surg 1986;152:127-32.

26. Nuutinen P, Kivisaari L, Schroder T. Contrast-enhanced computed tomography and microangiography of the pancreas in acute human hemorrhagic/necrotizing pancreatitis. Pancreas 1988;3:53-60.

27. Takada T, Yasuda H, Uchiyama K, Hasegawa H, Shikata J, Nagai J. CT score and the severity of acute pancreatitis. Int Surg 1988;73:94-8.

28. Clavien P-A, Hauser H, Meyer P, Rohner A. Value of contrast enhanced computerized tomography in the early diagnosis and prognosis of acute pancreatitis. A prospective study of 202 patients. Am J Surg 1988;155:457-66.

29. Balthazar EJ. CT diagnosis and staging of acute pancreatitis. Radiol Clin North Am 1989;27:19-37.

30. London NJM, Neoptolemos JP, Lavelle J, Bailey I, James D. Contrast-enhanced abdominal computed tomography scanning and prediction of severity of acute pancreatitis: a prospective study. Br J Surg 1989;76:268-72.

31. Bradley EL 3rd, Murphy F, Ferguson C. Prediction of pancreatic necrosis by dynamic pancreatography. Ann Surg 1989;210:495-504.

32. Marshall JC, Cook DJ, Christou NV, et al. Multiple organ dysfunction score, a reliable descriptor of a complex clinical outcome. Crit Care Med 1995;23:83-92

33. Buter A, Imrie CW, Carter CR, Evans S, McKay CJ. Dynamic nature of early organ dysfunction determines outcome in acute pancreatitis. Br J Surg 2002;89:298-302. 


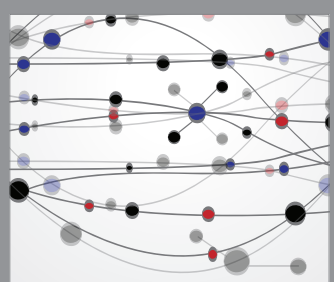

The Scientific World Journal
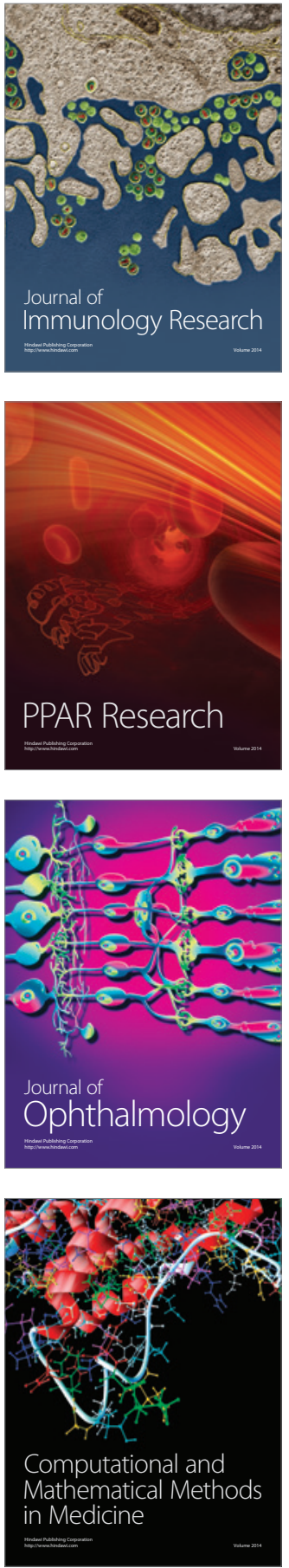

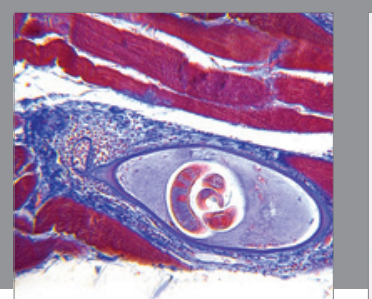

Gastroenterology Research and Practice

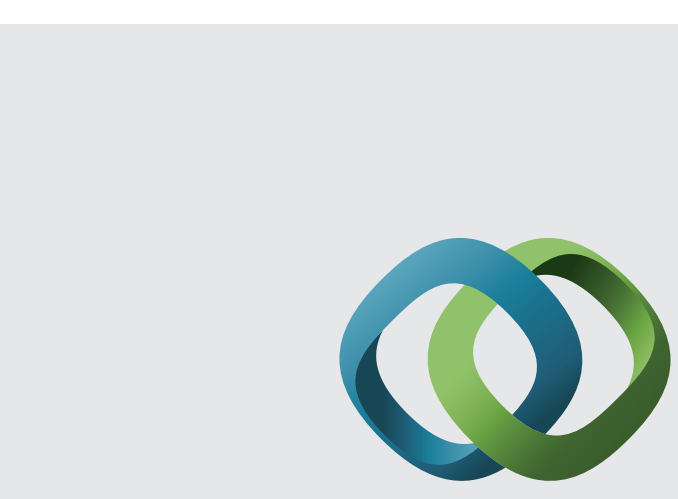

\section{Hindawi}

Submit your manuscripts at

http://www.hindawi.com
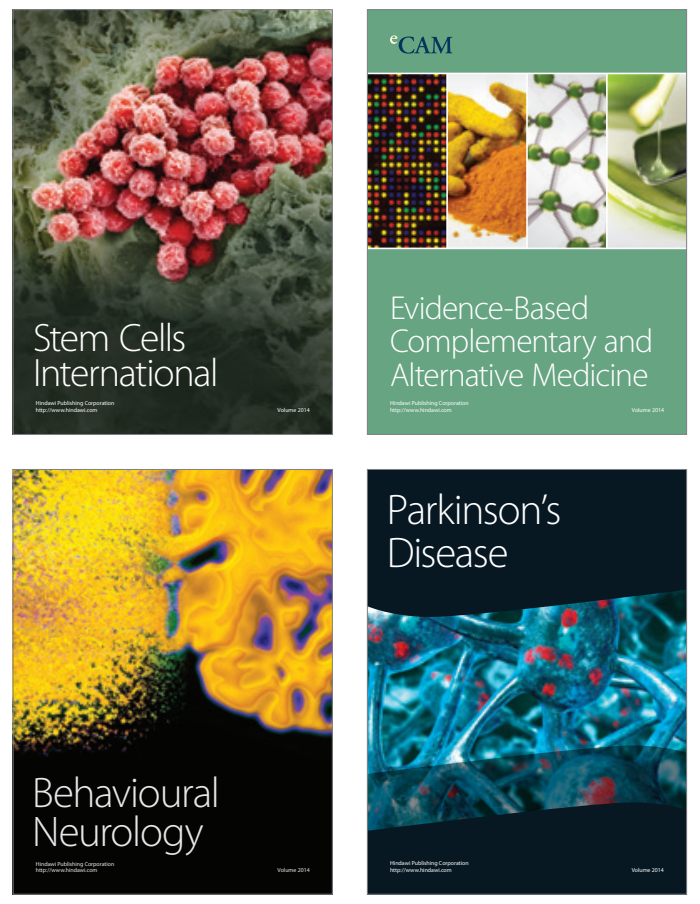
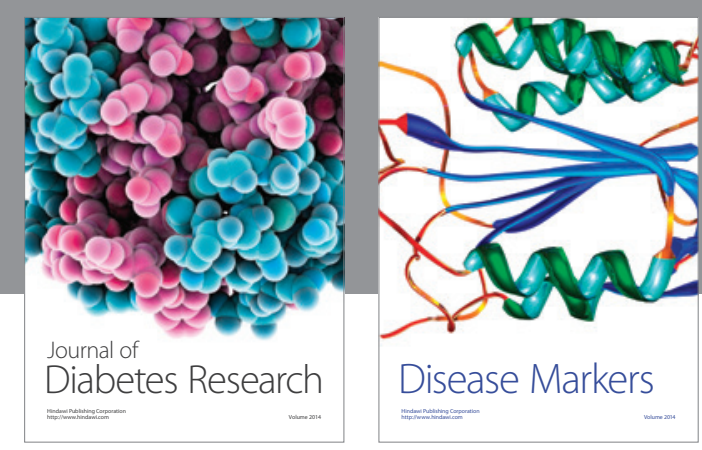

Disease Markers
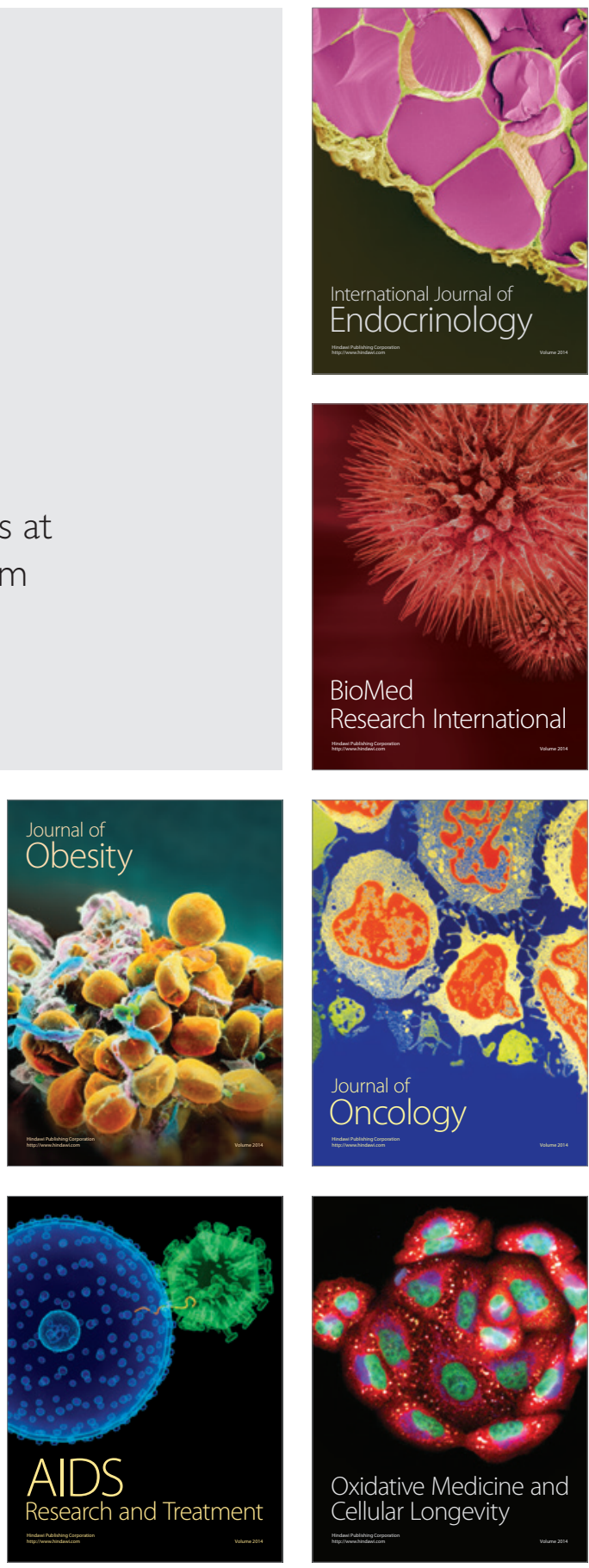